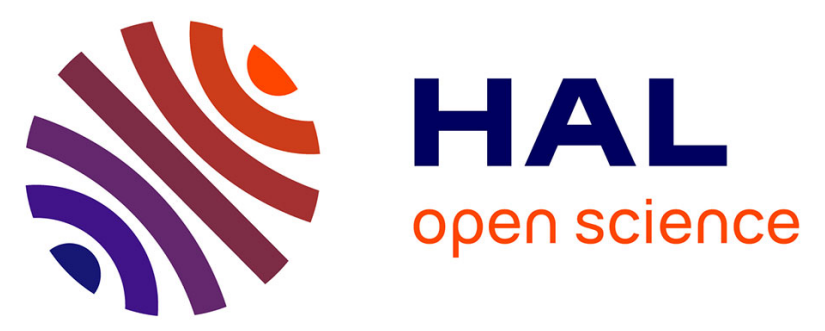

\title{
Assessment of the contributions of glycolysis and the pentose phosphate pathway to glucose respiration in ectomycorrhizas and non-mycorrhizal roots of spruce (Picea abies L. Karsten)
}

\author{
Isabelle Bilger, V. Guillot, Francis Martin, François F. Le Tacon
}

\section{To cite this version:}

Isabelle Bilger, V. Guillot, Francis Martin, François F. Le Tacon. Assessment of the contributions of glycolysis and the pentose phosphate pathway to glucose respiration in ectomycorrhizas and nonmycorrhizal roots of spruce (Picea abies L. Karsten). Annales des sciences forestières, 1989, 46 (suppl.), pp.724s-727s. hal-02726568

\section{HAL Id: hal-02726568 \\ https://hal.inrae.fr/hal-02726568}

Submitted on 2 Jun 2020

HAL is a multi-disciplinary open access archive for the deposit and dissemination of scientific research documents, whether they are published or not. The documents may come from teaching and research institutions in France or abroad, or from public or private research centers.
L'archive ouverte pluridisciplinaire HAL, est destinée au dépôt et à la diffusion de documents scientifiques de niveau recherche, publiés ou non, émanant des établissements d'enseignement et de recherche français ou étrangers, des laboratoires publics ou privés. 


\title{
Assessment of the contributions of glycolysis and the pentose phosphate pathway to glucose respiration in ectomycorrhizas and non-mycorrhizal roots of spruce (Picea abies L. Karsten)
}

\author{
I. Bilger, V. Guillot, F. Martin and F. Le Tacon
}

Laboratoire de Microbiologie Forestière, Centre de Recherches Forestières de Nancy, Institut National de la Recherche Agronomique, Champenoux 54280 Seichamps, France

\section{Introduction}

The importance of carbon supply in mycorrhizal infection and symbiotic activity has long been recognized. The supply of carbohydrates by the higher plant to the fungus is a very basic trait of mycorrhizal symbiosis. Mycorrhizal plants assimilate more photosynthates than non-mycorrhizal ones, allocate a greater fraction of the assimilated carbon to the root systems and lose a greater fraction of the assimilated carbon to respiratory $\mathrm{CO}_{2}$ than do non-mycorrhizal plants (for a review, see Martin et al., 1987). The establishment of a carbon sink by the ectomycorrhizal hyphae may be attained by: 1) rapid carbohydrate degradation for respiration and for energy and reducing power production and 2) conversion of plant carbohydrates into fungal biomass. The high respiration rate of fungal tissues has been pointed out by several authors (France and Reid, 1983). Most studies of mycorrhizal respiration deal with mitochondrial respiration. Much less is known about the oxidative metabolism of glucose in mycorrhizal roots. The substrate used as well as the pathways potentially involved in this process are not known.

The aim of this study was to determine the relative contribution of glycolysis and the pentose phosphate pathway to glucose oxidation in Norway spruce (Picea abies) ectomycorrhizas.

\section{Materials and Methods}

\section{Plant material}

Four year old plants of Picea abies L. Karsten, grown on a saridy soil, were sampled from a commercial bare-roots nursery (Merten, Vosges, eastern France). The plants were removed with attached soil, stored at $4^{\circ} \mathrm{C}$ and transferred to the laboratory. The root systems were washed with tap water and all soil particles were removed. The pyramidally branched ectomycorrhizas were pale brown, racemose with a prosenchymatous sheath, a thin mantle and an extensive Hartig net reaching to the endodermis. There were abundant extramatrical mycelia (Hebeloma sp.) interconnected with loosely woven, pale yellow mycelial cords (see Fig. 1 in Al-Abras et al., 1988; Dell et al., 1989). 
Assuming that the same chitin/protein ratio occurs in the mycelial cords of Hebeloma sp. and the fungal component of the ectomycorrhizas, then approximately $50 \%$ of the protein in the ectomycorrhizas is fungal (Dell et al., 1989).

\section{Radiorespirometry}

A radiorespirometry study was performed using ectomycorrhizal subsamples and the nonmycorrhizal apices of exploratory roots. This was done using a $10 \mathrm{ml}$ continuous ${ }^{14} \mathrm{CO}_{2}$ evolving and -trapping reaction flask. About 50 $\mathrm{mg}$ of fresh tissue were incubated in $5 \mathrm{ml}$ of distilled water containing $10 \mathrm{nmol}$ of $[1-14 \mathrm{C}]$ glucose or $11 \mathrm{nmol}$ of $\left[6-{ }^{-14}\right.$ C]glucose for $90 \mathrm{~min}$ at $22^{\circ} \mathrm{C}$. Experiments were started by the addition of $0.5 \mu \mathrm{Ci}(10.0 \mathrm{nmol})$ of suitably labeled $\left[{ }^{14} \mathrm{C}\right]$ glucose. An airflow of $200 \mathrm{ml} \cdot \mathrm{min}^{-1}$ was maintained and ${ }^{14} \mathrm{CO}_{2}$ was collected for $90 \mathrm{~min}$. Effluent air was passed directly into a $\mathrm{CO}_{2}$-trapping scintillation fluid containing an organic amine (Carbomax, Kontron) in $10 \mathrm{ml}$ vials and counted using a scintillation counter (Betamatic 1, Kontron). Residual radiolabel in the flask was determined by counting aliquots. Antibiotics were added to the incubation solution at the following concentrations to prevent bacterial activity: $0.02 \%(\mathrm{w} / \mathrm{v})$ penicillin, $0.04 \%(\mathrm{w} / \mathrm{v})$ streptomycin and $0.008 \%(\mathrm{~W} / \mathrm{v})$ aureomycin. Soluble compounds were then extracted according to Al-Abras et al. (1988) and radioactivity determined by counting $100 \mu$ l aliquots. Chitin was determined by measuring the amount of fungal glucosamine resulting from acid hydrolysis of chitin in mycorrhizal roots and mycelial cords using the method of Vignon et al. (1986).

\section{Statistical analysis}

Data are presented as means of 4 or 6 replicates. Variance analysis or mean comparison was performed on the logarithm of the percentages or ratios.

\section{Theoretical}

The approach used is based on the assumption that the initial yield of ${ }^{14} \mathrm{CO}_{2}$ from $\left[1-{ }^{14} \mathrm{C}\right] \mathrm{glu}$ cose represented glycolysis and the pentose phosphate pathway, whereas that from [6${ }^{14} \mathrm{C}$ ]glucose represented only glycolysis (Ap Rees, 1980). The following set of equations enables the contribution of the pentose phosphate pathway (PPP) to be calculated.

respiration rate $=\frac{\left(\text { released }{ }^{14} \mathrm{C} \text { as } \mathrm{CO}_{2} \times 100\right)}{\text { (released }{ }^{14} \mathrm{C} \text { as } \mathrm{CO}_{2}+\text { incorporated }{ }^{14} \mathrm{C} \text { in soluble compounds) }}$

specific yield of ${ }^{14} \mathrm{CO}_{2}=\frac{\left(\text { released }{ }^{14} \mathrm{C} \text { as }{ }^{14} \mathrm{CO}_{2} \times 100\right)}{\left(\text { released }{ }^{14} \mathrm{C} \text { as }{ }^{14} \mathrm{CO}_{2}+\text { incorporated }{ }^{14} \mathrm{C}\right)}$

$$
\begin{aligned}
& R_{1}=\frac{\text { (released }{ }^{14} \mathrm{C} \text { as }{ }^{14} \mathrm{CO}_{2} \text { from }\left[6-{ }^{14} \mathrm{C}\right] \text { glucose) }}{\text { (released }{ }^{14} \mathrm{C} \text { as }{ }^{14} \mathrm{CO}_{2} \text { from }\left[1-{ }^{14} \mathrm{C}\right] \text { glucose) }} \\
& R_{2}=\frac{\text { (specific yield of }{ }^{14} \mathrm{C} \text { from }\left[6-{ }^{-14} \mathrm{C}\right] \text { glucose) }}{\text { (specific yield of }{ }^{14} \mathrm{C} \text { from }[1-14 \mathrm{C}] \text { glucose) }}
\end{aligned}
$$

PPP contribution =

[(specific yield of ${ }^{14} \mathrm{CO}_{2}$ from $\left[1-{ }^{14} \mathrm{C}\right]$ glucose) - (specific yield of ${ }^{14} \mathrm{CO}_{2}$ from [6-14 $\mathrm{C}$ ]glucose)]

$\left(1-\right.$ specific yield of ${ }^{14} \mathrm{CO}_{2}$ from $[6-14 \mathrm{C}]$ glucose $)$ 
Table I. Respiration rate and $\mathrm{C} 6 / \mathrm{C} 1$ ratios of Hebeloma sp. ectomycorrhizas and non-mycorrhizal exploratory roots fed $[1-14 \mathrm{C}]$ glucose and $[6-14 \mathrm{C}]$ glucose.

\begin{tabular}{|c|c|c|c|c|c|}
\hline & $\begin{array}{l}\text { Respiration rate } \\
\text { from }[1-14 \mathrm{C}] \mathrm{glucose} \\
(\%)\end{array}$ & $\begin{array}{l}\text { Respiration rate } \\
\text { from }\left[6^{-14} \text { Clglucose }\right. \\
\text { (\%) }\end{array}$ & $\frac{C 6 / C}{R_{1}}$ & $\frac{\text { ratios }}{R_{2}}$ & $\begin{array}{l}\text { PPP } \\
\text { contribution } \\
\text { (\%) }\end{array}$ \\
\hline $\begin{array}{l}\text { Ectomycorrhizas } \\
\text { Non-mycorrhizal roots }\end{array}$ & $\begin{array}{l}53 \\
40\end{array}$ & $\begin{array}{r}7 \\
17\end{array}$ & $\begin{array}{l}0.1 \\
0.3\end{array}$ & $\begin{array}{l}0.13 \\
0.43\end{array}$ & $\begin{array}{l}49.5 \\
38.6\end{array}$ \\
\hline $\operatorname{LSD}(P=0.05)$ & + & + & + & + & + \\
\hline
\end{tabular}

For definition of respiration rate, $R_{1}, R_{2}$ and relative contribution (\%) of the pentose phosphate pathway (PPP) to glucose respiration, see Materials and Methods.

\section{Results and Discussion}

The radiorespirometric method was applied to non-mycorrhizal exploratory roots and young mycorrhizas. Both nonmycorrhizal roots and ectomycorrhizas showed virtual simultaneous emission of ${ }^{14} \mathrm{CO}_{2}$ from $\left[1-{ }^{14} \mathrm{C}\right]-$ and $\left[6-{ }^{14} \mathrm{C}\right]$ glucose with similar patterns (data not shown). These data indicated the operation of more than one oxidative pathway. The rapid and predominant release of ${ }^{14} \mathrm{CO}_{2}$ from $[1-14 \mathrm{C}]$ glucose coupled with low emission from $[6-14 \mathrm{C}]$ glucose, in both samples, implied both a minor role of the tricarboxylic acid cycle and relatively low recycling of labeled glucose through the non-oxidative part of the pentose phos- phate pathway and/or mannitol cycle (Martin et al., 1985).

Using an incubation period of $90 \mathrm{~min}$ in labeled glucose, the $\mathrm{C} 6 / \mathrm{C} 1$ ratios, $R_{1}$ and $R_{2}$ (Table I), were found to range from 0.10 to 0.13 for mycorrhizal roots and 0.30 to 0.43 for non-mycorrhizal ones. The low $\mathrm{C} 6 / \mathrm{C} 1$ ratios of the mycorrhizal roots suggests a high activity of the pentose phosphate pathway. The level of $\mathrm{CO}_{2}$ released from [6-14C]glucose was always comparatively lower. In non-mycorrhizal exploratory roots, $38 \%$ of the carbohydrate oxidation was via the pentose phosphate pathway and $62 \%$ was via glycolysis. On the other hand, $50 \%$ of the glucose metabolism from mycorrhizal roots was catalyzed by the pentose phosphate pathway,

Table II. Respiration rate and $\mathrm{C} 6 / \mathrm{C} 1$ ratios of various tissues from Hebeloma sp. ectomycorrhizas and non-mycorrhizal exploratory roots fed $\left[{ }^{14} \mathrm{C}\right]$ glucose.

\begin{tabular}{|c|c|c|c|c|c|}
\hline & \multirow{2}{*}{$\begin{array}{l}\text { Respiration rate } \\
\text { from }[1-14 \text { C]glucose } \\
\text { (\%) }\end{array}$} & \multirow{2}{*}{$\begin{array}{l}\text { Respiration rate } \\
\text { from }\left[6^{-14} \mathrm{C}\right] \text { glucose } \\
(\%)\end{array}$} & \multicolumn{2}{|c|}{ C6/C1 ratios } & \multirow{2}{*}{$\begin{array}{l}\text { PPP } \\
\text { contribution } \\
\text { (\%) }\end{array}$} \\
\hline & & & $\overline{R_{1}}$ & $\overline{R_{2}}$ & \\
\hline $\begin{array}{l}\text { Extramatrical hyphae } \\
\text { Fungal sheath } \\
\text { and root cortex }\end{array}$ & 50.8 & 10.1 & 0.21 & 0.19 & 45.3 \\
\hline including the Hartig net & $\begin{array}{l}51.5 \\
49 ?\end{array}$ & $\begin{array}{r}7.9 \\
16.4\end{array}$ & 0.13 & 0.14 & 48.4 \\
\hline $\begin{array}{l}\text { Root stele } \\
\text { LSD }(P=0.05)\end{array}$ & $\begin{array}{l}49.2 \\
n s\end{array}$ & $\begin{array}{c}16.4 \\
+\end{array}$ & $\begin{array}{l}0.29 \\
+\end{array}$ & $\begin{array}{l}0.30 \\
+\end{array}$ & $\begin{array}{c}39.4 \\
+\end{array}$ \\
\hline
\end{tabular}

For definition of respiration rate, $R_{1}, R_{2}$ and relative contribution (\%) of the pentose phosphate pathway (PPP) to 
demonstrating that the carbohydrate oxidative pathways are drastically altered in response to fungal colonization of the root.

To determine the distribution of the two catabolic pathways, mycorrhizal roots were further separated into extramatrical hyphae, symbiotic root tissues (mantle, Hartig net hyphae plus root cortex) and stele. The contribution of the pentose phosphate pathway was different in the various mycorrhizal tissues, being higher in symbiotic tissues $(49.2 \%)$ and extramatrical hyphae $(46.5 \%)$ (Table II). The contribution of the pentose phosphate pathway in the stele of mycorrhizal roots was identical to that of whole non-mycorrhizal roots and accounted for $40 \%$.

These differences between mycorrhizas and non-mycorrhizal roots and between fungal and host tissues suggest that the contribution of the pentose phosphate pathway to respiration is higher in the fungal component than in the plant tissues. The fact that the pentose phosphate pathway activity was even higher in root tissues colonized by the fungal cells (mantle and Hartig net) than in extramatrical hyphae suggests that the contribution of this oxidative pathway is stimulated when the root is associated with a symbiotic fungus. This increase in the pentose phosphate pathway activity may be related to the higher metabolic activity of the Hartig net revealed by ultrastructural studies of the host-fungus interface (many mitochondria and ribosomes, extensive development of the endoplasmic reticulum, lack of large vacuoles) (Kottke and Oberwinkler, 1986).

Whether there is an increase in the activity of the pentose phosphate pathway enzymes or changes in the respective polypeptide amounts during ectomycorrhiza formation must await further analysis.

\section{References}

Al-Abras K., Bilger I., Martin F., Le Tacon F. \& Lapeyrie F. (1988) Morphological and physiological changes in ectomycorrhizas of spruce [Picea excelsa (Lam.) Link] associated with ageing. New Phytol. 110, 535-540

Ap Rees T. (1980) Assessment of the contributions of metabolic pathways to plant respiration. In: The Biochemistry of Plants, A Comprehensive Treatise. Vol. 2 Metabolism and Respiration. (Stumpf P.K. \& Conn E.E., eds.), Academic Press, London, pp. 1-27

Dell B., Botton B., Martin F. \& Le Tacon F. (1989) Glutamate dehydrogenases in ectomycorrhizas of spruce [Picea excelsa (Lam.) Link] and beech (Fagus sylvatica L.). New Phytol. 111, 683-692

France R.C. \& Reid C.P.P. (1983) Interactions of nitrogen and carbon in the physiology of ectomycorrhizae. Can. J. Bot. 61, 964-984

Kottke I. \& Oberwinkler F. (1986) The cellular structure of the Hartig net: coenocytic and transfer cell-like organization. Nord. J. Bot. 7 , 85-95

Martin F., Canet D. \& Marchal J.P. (1985) ${ }^{13} \mathrm{C}$ nuclear magnetic resonance study of mannitol cycle and trehalose synthesis during glucose utilization by the ectomycorrhizal ascomycete Cenococcum graniforme. Plant Physiol. 77, 499-502

Martin F., Ramstedt M. \& Söderhäll K. (1987) Carbon and nitrogen metabolism in ectomycorrhizal fungi and ectomycorrhizas. Biochimie 69, 569-581

Vignon C., Plassard C., Mousain D. \& Salsac L. (1986) Assay of fungal chitin and estimation of mycorrhizal infection. Physiol. Vég. 24, 201-207 